IZA DP No. 9184

Worker-level and Firm-level Effects of a Wage Subsidy Program for Highly Educated Labor: Evidence from Denmark

Ulrich Kaiser

Johan M. Kuhn

July 2015 


\title{
Worker-level and Firm-level Effects of a Wage Subsidy Program for Highly Educated Labor: Evidence from Denmark
}

\author{
Ulrich Kaiser \\ University of Zurich, \\ CEBR, Copenhagen Business School, ZEW and IZA \\ Johan M. Kuhn \\ EPAC and Copenhagen Business School
}
Discussion Paper No. 9184
July 2015

IZA

P.O. Box 7240

53072 Bonn

Germany

Phone: +49-228-3894-0

Fax: +49-228-3894-180

E-mail: iza@iza.org

\begin{abstract}
Any opinions expressed here are those of the author(s) and not those of IZA. Research published in this series may include views on policy, but the institute itself takes no institutional policy positions. The IZA research network is committed to the IZA Guiding Principles of Research Integrity.

The Institute for the Study of Labor (IZA) in Bonn is a local and virtual international research center and a place of communication between science, politics and business. IZA is an independent nonprofit organization supported by Deutsche Post Foundation. The center is associated with the University of Bonn and offers a stimulating research environment through its international network, workshops and conferences, data service, project support, research visits and doctoral program. IZA engages in (i) original and internationally competitive research in all fields of labor economics, (ii) development of policy concepts, and (iii) dissemination of research results and concepts to the interested public.
\end{abstract}

IZA Discussion Papers often represent preliminary work and are circulated to encourage discussion. Citation of such a paper should account for its provisional character. A revised version may be available directly from the author. 


\section{ABSTRACT}

\section{Worker-level and Firm-level Effects of a Wage Subsidy Program for Highly Educated Labor: Evidence from Denmark ${ }^{*}$}

We study the effects of a Danish wage subsidy program for highly educated workers on the labor market outcomes of the persons participating in the program and on the performance of the firms that hired these subsidized workers. Using data on the population of program participants, both individuals and firms, we find that the program had positive effects on employment and wages the year individuals participate in the program. For wages, we also find positive and statistically significant effects for the two subsequent years. At the program participating firm level, we find statistically significant effects on the number of highly educated employees for both the period of program participation and the subsequent time period.

JEL Classification: D04, O31, O38

Keywords: wage subsidies, firm performance, program evaluation

Corresponding author:

Ulrich Kaiser

University of Zurich

Department of Business Administration

Affolternstrasse 56

8050 Zurich

Switzerland

E-mail: ulrich.kaiser@business.uzh.ch

\footnotetext{
*We gratefully acknowledge very helpful comments from Thomas Alslev Christensen (Novo Nordisk Foundation) and Klaus Ammitzbøll (The Danish Agency for Science, Technology and Innovation, DASTI), Christan M. Dahl, Søren Bo Nielsen, Anders Sørensen and seminar participants at the Danish Research Unit for Industrial Dynamics (DRUID). We thank DASTI for partially sponsoring this research and for making the wage subsidy program data available for research.
} 


\section{Introduction}

Increasingly high unemployment rates for high skilled labor have recently induced politicians to call for active labor market policy measures as perhaps best reflected by the Council of the European Union recommendation "to adopt measures at national level which are aimed at increasing the employability of graduates leaving the education and training system" in May 2012. ${ }^{1}$ Policy makers at the local, regional and national level have indeed started a fair number of initiatives of which Appendix A provides an overview. A formal evaluation of such programs is, however, still lacking.

This paper studies an early active labor market program for individuals with a post-secondary or tertiary-level education, the Danish "innovation assistant" (hereafter "IA") wage subsidy program. The program served the dual purpose of getting more academics into employment and at transferring academic knowledge to SMEs since they have historically been reluctant to hire high qualified labor in Denmark and elsewhere. The IA program was launched by the Danish Agency for Science, Technology and Innovation (DASTI) in 2005 when the unemplyment rate for high skilled workers was 3.7 percent and considered high given an average unemployment rate of 4.8 percent and the cost of educating high skilled labor. ${ }^{2}$

The evaluation of active labor market policy programs constitutes both a wellresearched topic on the agenda of applied labor economists and an important issue for policy makers. Existing studies almost exclusively deal with programs geared at low skilled labor since this type of workers is most adversely affected by technological change. ${ }^{3}$ In addition, given the focus on labor market outcomes of individuals, comparatively little is known about the effects of training or wage subsidy programs on the performance of the firms that are involved.

Our evaluation of the Danish IA program studies the effect of the subsidy on both persons and firms. We ask, (i) how do individuals who participate in the programme perform with regard to their employment and income and (ii) how do participating companies perform in terms of employment, productivity and other success criteria.

Eligible for the IA program were privately owned firms with at least two and at most 100 employees whereof no more than two may have been academics. In addition, firms needed to exist for at least one year and must make more than DKK 1 million (Euro 130,000) in revenues. SMEs needed to specify a specific development project that the IA was supposed to carry out. Firms that successfully applied for funding through the IA program received a wage subsidy of up to half of the IAs salary, with a

\footnotetext{
${ }^{1}$ Source: http://www.parlament.gv.at/PAKT/EU/XXIV/EU/08/02/EU_80203/imfname_10027589.pdf.

${ }^{2}$ According to our own calculations based on Eurostat data on unemployment rates by highest level of education attained, the Danish unemployment rate for high skilled labor increased to 4.6 percent in 2013, comparing to a seven percent average. In addition, the gap in unemployment rates between low skilled and high skilled labor has steadily decreased between 2004 and 2013, both in Denmark and EU-wide. The unemployment rate differences between high skilled and low skilled labor is diminishing in countries such as Greece, Spain, Italy, Cyprus, Portugal, Romania and Iceland that were hard hit by the recent financial crisis.

${ }^{3}$ Reviews of the extant literature are provided by Card et al. (2010), Dar and Tzannatos (1999), Heckman et al. (1999), Kluve (2010) as well as Martin and Grubb (2001).
} 
maximum of DKK 12,500 (Euro 1,700) per month - about half the average monthly wage in our data - for a period between six and twelve months.

We do unfortunately not know much about how IA projects were initiated. Anecdotal evidence that we have collected does indicate, however, that it was mostly the potential IA who contacted the SME and suggested an employment relationship under the IA program. While we do not know anything about the mechanisms that match potential IAs with potential hosts, we do know that essentially all applications for wage subsidies were eventually granted.

To analyze the IA program, we use the population of 364 persons and 316 firms that ever participated in the scheme between 2005 and 2010. In order to cope with potential self-selection problems of firms and individuals into the program, we apply "conditional differences in differences" (cDID) estimation methods (Heckman et al. 1998, 1999) where we first use econometric matching models and subsequently run firm-performance and labor market outcome regressions on the matched data to additionally take into account both observable and unobservable time-invariant factors that may determine the selection into program participation (Blundell and Costa Dias 2009, Ch. V.E). Similar approaches have previously been applied in the program evaluation literature by Almus and Czarnitzki (2003), Brandstetter and Sakakibara (1998) as well as Kaiser and Kuhn (2011).

At the person level, we consider the probability of an IA to be employed after having entered the program in subsequent time periods as well as her absolute wage increase as outcome variables. At the firm level, we analyze the total number of highly educated employees, the total number of employees, value added, net income, return on assets, total wage per employee and labor productivity (sales per employee) as outcome variables. At the person-level, we find that the IA program had positive wage and employment effects in the year of program participation as it should be by construction. We do also, however, find that there also are economically and statistically significant wage effects for the two years subsequent to program participation. At the SME-level, we find positive effects on the number of highly skilled employees for both the period of program participation and the subsequent time period.

\section{Data}

Our data stem from three main sources, (i) DASTI which contains information on individual VP-projects, an identifier for both the participating IA and the corresponding SME and the starting date of the project, (ii) Experian A/S, a credit rating agency whose financial reports has been used in prior research by Kaiser and Kuhn (2012) and (iii) Statistics Denmark which provides a matched employer-employee data base including information on both individuals and firms.

The DASTI data constitute the key element of our full data set as it contains unique identifiers for both participating employers and employees. These identifiers allow us to uniquely match individuals and firms to the Experian and Statistics Den- 
mark data. The DASTI data also contains information on when the IA project was started.

The Statistics Denmark data contains annual information on a wide range of person-level and firm-level characteristics of which we use demographic information, information on education, wage and occupation for individuals and the number of employees and turnover for firms. This data was available to us up to the year 2010 and covers the population of Danish firms and individuals.

The Experian data consists of approximately 1.7 million financial records in the period 2000 to 2010 , our time period under consideration. The timing of the records is based on the closing dates of the financial report periods. When we merged the information from Statistics Denmark with the Experian data, we used the information most closely related in time to the Statistics Denmark registers.

We identify a total of 416 IAs in the DASTI data of which we could not trace six in the register data at all. Information on the highest educational degree was not available for 16 individuals that needed to be discarded as well which leaves us with 394 IAs.

At the employer level, a total of 370 companies have hosted IA projects and are also found in the Experian database the year before they started program participation. The remaining 230 SMEs that we could not match with the Experian data are likely to be unincorporated and thus not obliged to submit financial reports to the authorities. We are able to track firms until 2009 in the Statistics Denmark data and until 2011 in the Experian data. We observe firms for 6.7 years on average.

\section{Empirical approach}

For both the analysis of person-level and firm-level effects we first match treatment and potential control group observations on their observed characteristics in the year before starting treatment, i.e. before entering the IA program. We subsequently run multivariate regressions on the matched treatment/control data.

\subsection{Propensity score matching}

There exist various econometric matching models that are very well described in the reviews by Blundell and Costa Dias (2009) as well as Caliendo and Kopeinig (2008). A common feature of these models is that they trade bias against precision. Bias is increasing in the dissimilarities between treatments and controls, while precision is increasing in the size of the control group. We closely follow Kaiser and Kuhn (2012) by applying nearest neighbor caliper matching with a single neighbor and replacement since we aim at minimizing bias and since the results of the matching procedure are not of original interest to us. We match on the propensity score which simply constitutes the predicted probability of program participation. We calculate the propensity score from a binary logit regression that controls for a wide range of variables that are likely 
to affect both treatment choice and performance. We proceed the same way for both individuals and firms.

While we do control for a large set of relevant variables that are known to affect both firm performance and selection, we cannot formally test if the outcome variables are indeed independent of treatment conditional on our set of conditioning variables — e.g., if the "conditional independence assumption" indeed met. What we can test, however, is whether the "balancing property" is satisfied, i.e., if treatment and control groups observations are no longer statistically different from one another in terms of observed characteristics after matching. An additional condition for our identification strategy to hold is the "common support" requirement. It rules out that the probability of treatment is perfectly predicted by the set of conditioning variables. It ensures that individuals with the same observed characteristics have a positive probability of receiving both treatment and non-treatment (Heckman et al. 1999). Anticipating our estimation results we note that all our matched control observations are on the common support.

All estimations are performed using Stata 11.0. We use the "psmatch2" module by Leuven and Sianesi (2003) implemented in Stata to perform our propensity score matching estimations.

\subsection{Conditional differences-in-differences estimation}

With a sample of treatment and observationally highly similar control observations at hand we run multivariate regressions on outcomes. The idea behind additionally running multivariate regressions on the matched data is to remove any differences between treatment and control observations that may be left after matching. In addition, the panel structure of our data allows us to control for individual-specific and firm-specific time-invariant differences that else would go unnoticed.

\section{Individual-specific analysis}

In a first step of our person-level analysis, we remove any control group observations with characteristics not observed in the set of treatment observations. For example, we discard individuals with a formal education not found in the treatment group. In a second step, we run logit regressions of the probability of receiving treatment at time $t$ on a rich set of explanatory variables that we measure at time $t-1$, the year before they move into the program. Our set of conditioning variables includes (i) demographic information like age, gender and marital status, (ii) information on the individuals' highest level of formal education which includes a total of 15 different categories, (iii) a dummy variable that specifies whether or not the individual is currently enrolled in an education program, (iv) the average high school degree and sets of dummy variables for the individuals' high school majors, (v) an individuals' occupational status like employment, unemployment or parental leave, (vi) wage income, (vii) years of labor market experience and (viii) geographical location of residence. In a third step, we use the propensity score generated by our logit model to match 
our treatment to our control group observations. We match them exactly in terms of education, gender and occupational status. In a fourth and final step, we run two "performance" regressions based on the matched treatment and control group data, considering whether or not an individual is in wage-employment - which we evaluate using a logit model - and second, what her wage increase is compared to the year before entering the IA program. We evaluate the latter running OLS regressions. We condition on a very similar set of variables that we use for our propensity score matching in both regressions, again all conditioned at time $t-1$ and hence time-invariant. Given that the number of observations substantially decreases after matching, we need to, however, lump together some dummy variables. We run year-by-year regressions to allow the treatment effects to vary over time.

\section{Firm-specific analysis}

Our firm-specific analysis essentially proceeds in the same four steps as our personspecific one. We first select a pool of potential controls in the Experian data by removing firms operating in industries without any participating firms, with ownership types not found among the treated firms and companies larger than 150 employees since they are not eligible for program participation. We could trace 370 out of the 434 SMEs that have hosted IA projects in the Experian data. After data cleaning we are left with a sample of 316 treatment group firms.

We partition our set of participating firms by year and industry. Within each group, we identify a matched control group observation on the basis of the propensity score which conditions on sets of industry dummies, the number employees and their formal education, net income, return on assets, wage costs per employee, labor productivity, total assets, equity share, short-term debt and time dummies. These variables are all measured at time $t-1$. Following Kaiser and Kuhn (2012), we finally estimate dynamic fixed-effects regressions for our seven firm performance indicators number of employees, number of highly educated employees, value added, net income, return on assets, wage per employee and labor productivity on the matched data. Our estimation equation is:

$$
Y_{i t}-Y_{i t-1}=\sum_{j=1}^{5}\left(\alpha_{j} D\left(t_{i}=j\right)+\beta_{j}\left(D(\text { treat }=1) * D\left(t_{i}=j\right)\right)\right)+u_{i}+\epsilon_{i t},
$$

where $Y$ denotes the respective performance measure, $i$ is the firm index, $t$ the time index, vector $\boldsymbol{x}_{\boldsymbol{i}}$ denotes a set of time dummies, and the $D$ denote dummy-operators that are coded one if the respective condition in parentheses holds. The specification accounts for fixed effects $u_{i}$ which is why all time-invariant variables such as our set of conditioning variables in the previous steps drop out. The $\alpha$ coefficients denote time fixed effects and the $\beta$ coefficients denote the year-specific treatments effects. 


\section{Results}

\subsection{Person-specific results}

We identify a total of 394 individuals that we could match to the registers of Statistics Denmark and we search for control individuals from the total untreated population of $1,018,245$ individuals in the register data. Appendix B displays descriptive statistics of the variables involved in our estimations for both treated and control persons. The Appendix shows that program participants and control group individuals differ substantially from one another with respect to age, experience, pre-treatment wage, marital status, type of education and region of residence. The only dimensions where there is comparatively little difference are high school grades and gender. Individuals participating in the program are comparatively younger, are more likely to be from more rural areas, have had more years of unemployment and receive a lower salary. The person-level program selection logit estimation results displayed in Appendix C corroborate the findings of the means comparisons in Appendix B which is why we do not discuss them further. We needed to discard 30 program participants since there was no control group individual identical in terms of education, gender, occupation and age, the characteristics on which we matched exactly.

After matching, the once strong differences in observed characteristics have vanished. Since we condition on the propensity score alone instead of the individual conditioning variables, we need to assess if our selected set of control group observations indeed match well with our set of treatment observations. To this end, we Rosenbaum and Rubin's (1985) "standardized biases", the mean differences between treatment and control group observations before and after matching, weighted by their standard deviations. Appendix B displays these standardized biases before and after matching. None of these differences are statistically significant which is why we do not display the corresponding $p$-values. As an additional match quality check, Sianesi (2004) suggests using the pseudo $R^{2}$ of a logit model for selection into treatment on the matched data. Since there should not exist significant differences in the distribution of the conditioning variables after matching, the pseudo $R^{2}$ should be close to 0 . Similarly, tests for joint significance of the conditioning variables should not turn out to be statistically significant. The pseudo $R^{2}$ after matching is 0.032 in our case and tests for joint significance cannot reject that the covariates are statistically highly insignificant as well. These tests hence indicate that our control group is well matched to our treatment group based on observed individual characteristics.

Table 1 displays our year-by-year cDiD estimation results for the probability of being wage-employed at a time period subsequent to having entered treatment. We only show the treatment effect dummy variable of the regressions for brevity. The table shows that there only are statistically significant effects for the year when an individual entered the IA program while there are no such effects for any of the four additional time periods we consider.

The results of our wage increase regressions, shown in Table 2, are a bit less gloomy: 
we do of course also find one-off effects for the year of program participation. We do, however, also find statistically significant effects for year two and three after program entry. The first year effect is 56,456 DKK on average while the second and third year effects are around 22,000 DKK.

\subsection{Firm-specific results}

Our set of potential control group SMEs to the 370 treatment group SME includes information on 296,000 firms. We were able to find matches for all but two treatment group firms. Appendix D displays descriptive statistics for the variables we include in our analysis. As for the individual-level analysis, we find major and statistically significant differences between treatment and control group observations before matching. Firms that are most likely to be in the treatment group are those that are not in the construction industry, that are incorporated, are relatively large, have high returns on assets, a relatively low equity share, a low average employee age, a high share of highly educated employees, and a low share of employees with primary school as their highest level of education. Finally, the program is more popular in more rural areas.

We again run a logit model to calculate the propensity score and to use that score to match our treatment and control group firms. The corresponding estimation results are displayed in Appendix E and again are well in line with the descriptive statistics discussed above. As shown in Appendix D, the formerly substantial and economically as well as statistically significant differences between firms before matching vanish after we have matched them on their propensity scores. After matching, none of these differences described above is statistically significant any more. In addition, the pseudo $R^{2}$ of a logit regression on the matched data is 0.04 . The corresponding test for joint significance is statistically highly insignificant, again indicating that we match treatment and control observations very well.

Table 3 displays our cDiD fixed effects estimation results. The coefficients displayed correspond to the difference IA program participation makes for our outcome variables compared to firms that did not participate in the IA program. We again and unsurprisingly find one-off effects of IA participation for the year of program participation on the number of employees and the number of high skilled employees. For the latter outcome variable we also find statistically significant effects for the subsequent time period. We do neither find any evidence for the program having any effect on either these variables in subsequent years nor do we find any statistically significant effects for the other outcome variables we consider.

\section{Conclusions}

During the recent economic crisis, unemployment rates have substantially increased even of highly skilled labor. As a consequence, politicians across Europe have called for actions to combat this trend and many actions have already been implemented in particular at the regional and local level. While active labor market policy programs 
are well evaluated for low skilled labor, little is known about their consequences for high-skilled labor and for the firms that hire individuals from such programs.

To contribute to the debate on active labor market programs for high skilled labor, our paper analyzed the consequences of a wage subsidy program for workers with higher secondary and tertiary education that was started in Denmark in 2005. We used data on the population of individuals and firms enrolled in the "Innovation assistant" program to study the effects of the scheme on both individuals' labor market outcomes and firms' performance using conditional difference-in-differences analysis where we control for a wide range of observed characteristics.

At the person-level we find that the program only had one-off effects on employment and wages during program participation. For wages we additionally find statistically and economically significant effects for the two years after an individual left the program. At the firm level, while the program of course increased both the number of workers and the number of high-skilled workers during program participation, these effects were short-lived and wore out after program expiration.

The program did not only aim at bringing unemployed academics into work, it was additional geared at bringing academic knowledge into SMEs. We also did consider a direct innovation-related variable, patent application counts using the data explored in Kaiser et al. (2015). There were only two firms with at least one patent during the period under investigation which is why we had to refrain from an analysis of the IA program on innovative activity.

The IA has been replaced by the "InnoBooster" (http://innovationsfonden.dk/da/ investeringstype/innoboster) in February 2015. The new scheme also pays wage subsidies to firms hiring academics but that has much stricter requirements for program admittance. The application must now be more detailed in pinning down what exactly the new innovative activities of the firm will be, and, most importantly, that the project is commercially relevant to the SME. An evaluation of this more precisely defined program is left for further research. 


\section{References}

Almus, M., Czarnitzki, D., 2003. The Effects of Public R\&D Subsidies on Firms' Innovation Activities: The Case of Eastern Germany. Journal of Business \& Economic Statistics 21(2), 226-36.

Blundell, R., Costa Dias, M., 2009. Alternative Approaches to Evaluation in Empirical Microeconomics. Journal of Human Resources 44(3), 565-640.

Branstetter, L., Sakakibara, M., 1998. Japanese Research Consortia: A Microeconometric Analysis of Industrial Policy. Journal of Industrial Economics 46 (2), 207-33.

Caliendo, M., Kopeinig, S., 2008. Some Practical Guidance for the Implementation of Propensity Score Matching. Journal of Economic Surveys 22(1), 31-72.

Card, D., Kluve, J., Weber, A., 2010. Active labor market policy evaluations: a meta-analysis. The Economic Journal 120, F452-F477.

Dar, A., Tzannatos, Z., 1999. Active labor market programs: a review of the evidence from evaluations. The World Bank SP discussion paper 9901; http://documents.worldbank.org/curated/en/1999/01/437973/active-labor-marketprograms-review-evidence-evaluations.

Heckman, J., Ichimura, H., Smith, J., Todd, P., 1998. Characterizing selection bias using experimental data. Econometrica 66, 1017-1098.

Heckman, J., LaLonde, R., Smith, J., 1999. The economics and econometrics of active labor market programs. In O. Ashenfelter and D. Card (eds), Handbook of Labor Economics, Amsterdam: Elsevier 1865-2097.

Kaiser, U., Kuhn, J.M., 2012. Long-run effects of public-private research joint ventures: the case of the Danish innovation consortia support scheme. Research Policy 41(5), 913-927.

Kaiser, U., Kongsted, H.C., Rønde, T., 2015. Does the mobility of R\&D labor increase innovation? Journal of Economic Behavior and Organization 110, 91105.

Kluve, J. (2010). The effectiveness of European active labor market programs, Labour Economics 17(6), 904-918.

Leuven, E., Sianesi, B. (2003). PSMATCH2: Stata module to perform full Mahalanobis and propensity score matching, common support graphing, and covariate imbalance testing; http://ideas.repec.org/c/boc/bocode/s432001.html.

Martin, J.P., Grubb, D., 2001. What works and for whom: a review of OECD countries' experiences with active labour market policies, Office of Labour Market Policy Evaluation 2001-14; http://www.ifau.se/upload/pdf/se/2001/wp01-14.pdf.

Rosenbaum, P.R., Rubin, D.B., 1985. Constructing a control group using multivariate matched sampling methods that incorporate the propensity score. The American Statistician 39 (1), 33-38. 
Table 1

ATT logit estimation results for IA-treatment person being employed in $\mathrm{t}=1$ to to=5 on matched data

\begin{tabular}{|l|l|l|l|}
\hline Treatment effect in: & Coeff. & Std.err. & \# obs. \\
\hline$t=1$ & $2.365^{* * *}$ & 0.350 & 568 \\
\hline$t=2$ & 0.271 & 0.293 & 486 \\
\hline$t=3$ & 0.577 & 0.354 & 383 \\
\hline$t=4$ & -0.423 & 0.408 & 286 \\
\hline$t=5$ & 0.282 & 0.716 & 199 \\
\hline
\end{tabular}

Notes: the logit model is run on the matched data and includes the following additional sets of control variables that were set to their pretreatment $(t=0)$ values: age, gender, annual wage, years of experience, marital status, schooling, occupation, immigration and region. It also contains a set of time dummies. Reading example: program participation increases the odds of being in employment by a factor of $\exp (2.218)=10.5$, an effect that is statistically highly significant.

Table 2

OLS regression results for absolute wage increase between $\mathrm{t}=0$ and the subsequent five time periods

\begin{tabular}{|l|l|l|l|l|}
\hline $\begin{array}{l}\text { Treatment effect } \\
\text { for time period: }\end{array}$ & Coeff. & Std.err. & \# obs. & R2 \\
\hline$t=0$ and $t=1$ & $56456^{* * *}$ & 8534 & 596 & 0.28 \\
\hline$t=0$ and $t=2$ & $21773^{*}$ & 12193 & 492 & 0.37 \\
\hline$t=0$ and $t=3$ & $25310^{*}$ & 14264 & 386 & 0.38 \\
\hline$t=0$ and $t=4$ & 4721 & 18928 & 293 & 0.48 \\
\hline$t=0$ and $t=5$ & 42096 & 34214 & 129 & 0.57 \\
\hline
\end{tabular}

Notes: the OLS model is run on the matched data and includes the following additional sets of control variables that were set to their pretreatment $(t=0)$ values: age, gender, annual wage, years of experience, marital status, schooling, occupation, immigration and region. It also contains a set of time dummies. Reading example: program participation increases the absolute wage rate by 56456 DKK, an effect that is statistically highly significant. 
Table 3

Fixed effects regression results for alternative outcome variables on matched data in $t=1$ to $t=5$

\begin{tabular}{|c|c|c|c|c|c|}
\hline & Coeff. & Std.err. & \# obs. & \# firms & $\mathrm{R} 2$ \\
\hline \multicolumn{6}{|c|}{ \# highly educated employees } \\
\hline $\mathrm{t}=1$ & $0.458^{* * *}$ & 0.12 & 2609 & 535 & 0.03 \\
\hline $\mathrm{t}=2$ & $0.318^{* *}$ & 0.14 & & & \\
\hline$t=3$ & 0.01 & .17 & & & \\
\hline$t=4$ & -0.14 & .21 & & & \\
\hline$t=5$ & -0.22 & .26 & & & \\
\hline \multicolumn{6}{|c|}{ \# of employees } \\
\hline$t=1$ & $0.596^{* *}$ & 0.30 & 2611 & 533 & 0.08 \\
\hline$t=2$ & 0.00 & 0.34 & & & \\
\hline$t=3$ & 0.33 & 0.40 & & & \\
\hline $\mathrm{t}=4$ & -0.45 & 0.60 & & & \\
\hline$t=5$ & -0.69 & 0.65 & & & \\
\hline \multicolumn{6}{|c|}{ Value added (in 1,000 DKK) } \\
\hline$t=1$ & 219.3 & 217.2 & 2611 & 533 & 0.04 \\
\hline $\mathrm{t}=2$ & 374.1 & 239.6 & & & \\
\hline$t=3$ & 165.2 & 324.2 & & & \\
\hline $\mathrm{t}=4$ & 124.0 & 448.2 & & & \\
\hline$t=5$ & -563.1 & 580.3 & & & \\
\hline \multicolumn{6}{|c|}{ Net income (in 1,000 DKK) } \\
\hline$t=1$ & -48.5 & 95.2 & 2553 & 542 & 0.03 \\
\hline $\mathrm{t}=2$ & 136.5 & 111.4 & & & \\
\hline$t=3$ & 133.3 & 122.1 & & & \\
\hline $\mathrm{t}=4$ & 205.5 & 218.1 & & & \\
\hline$t=5$ & -103.5 & 189.2 & & & \\
\hline \multicolumn{6}{|c|}{ Return on assets } \\
\hline$t=1$ & -0.03 & 0.02 & 2669 & 544 & 0.02 \\
\hline $\mathrm{t}=2$ & -0.04 & 0.03 & & & \\
\hline $\mathrm{t}=3$ & 0.00 & 0.03 & & & \\
\hline $\mathrm{t}=4$ & -0.04 & 0.04 & & & \\
\hline$t=5$ & -0.04 & 0.06 & & & \\
\hline \multicolumn{6}{|c|}{ Wage per employee (in 1,000 DKK) } \\
\hline$t=1$ & 8.28 & 11.26 & & & \\
\hline $\mathrm{t}=2$ & 5.25 & 10.27 & 1494 & 346 & 0.01 \\
\hline$t=3$ & -21.34 & 13.79 & & & \\
\hline $\mathrm{t}=4$ & 16.06 & 17.18 & & & \\
\hline$t=5$ & -19.32 & 29.92 & & & \\
\hline \multicolumn{6}{|c|}{ Labor productivity (in 1,000 DKK) } \\
\hline $\mathrm{t}=1$ & -27.92 & 93.59 & 1693 & 323 & 0.02 \\
\hline $\mathrm{t}=2$ & 57.28 & 107.90 & & & \\
\hline $\mathrm{t}=3$ & -137.30 & 91.84 & & & \\
\hline $\mathrm{t}=4$ & -39.23 & 134.00 & & & \\
\hline$t=5$ & -159.70 & 215.30 & & & \\
\hline
\end{tabular}

Notes: all models are estimated using fixed effects on the matched data. They also include a set of time dummies and a constant term.

Reading example: the number of highly educated workers increases by 0.458 workers compared to the set of control group firms one year after treatment. This effect is statistically highly significant. 
Appendix A: similar programs

Local

Milan: http://www.eciaplatform.eu/wp-content/uploads/2014/06/Thematic-paper-Innovation-

vouchers-Milan.pdf

Berlin: https://www.berlin.de/jobcenter/neukoelln/

Vienna: http://www.akzent-wien.at/

Regional

Baden-Wurttemberg (Germany): http://www.deutschland-startet.de/innovationsgutschein-badenwurttemberg/

Bavaria (Germany): http://www.innovationsgutschein-bayern.de/antragstellung.html

Brandenburg (Germany): https://www.zab-brandenburg.de/en/Our-Service/Promotion-

Consulting/Federal-Funding/Innovation-Vouchers-\%E2\%80\%9CGo-Innovative\%E2\%80\%9D-Module

\section{National}

Germany: http://www.bmbf.de/foerderungen/17739.php

Ireland: http://www.enterprise-ireland.com/en/Research-Innovation/Companies/Collaborate-withcompanies-research-institutes/Innovation-Voucher.shortcut.html

Montenegro: http://www.oecd.org/investmentcompact/Montenegro\%20English\%20Version.pdf 
Appendix B: person-level summary statistics

\begin{tabular}{|c|c|c|c|c|c|c|c|c|}
\hline \multirow[b]{2}{*}{ Variable } & \multicolumn{2}{|c|}{$\begin{array}{l}\text { Adjusted sample excluding } \\
V \operatorname{Vs}(N=1.018 .245)\end{array}$} & \multicolumn{2}{|c|}{$\begin{array}{l}\text { Treatment group } \\
(N=394)\end{array}$} & \multicolumn{2}{|c|}{$\begin{array}{l}\text { Analysis sample, } \\
\text { Treatments }(N=364)\end{array}$} & \multicolumn{2}{|c|}{$\begin{array}{l}\text { Analysis sample, } \\
\text { Controls }(N=364)\end{array}$} \\
\hline & Mean & Std. dev & Mean & Std. Dev. & Mean & Std. Dev. & Mean & Std. Dev. \\
\hline \multicolumn{9}{|l|}{ General information } \\
\hline Age (years) & 37.176 & 11.358 & 34.226 & 9.380 & 34.162 & 9.426 & 34.110 & 9.627 \\
\hline Female & 0.401 & 0.490 & 0.419 & 0.494 & 0.409 & 0.492 & 0.409 & 0.492 \\
\hline Experience (years, since 1980) & 10.483 & 8.169 & 6.104 & 6.669 & 6.203 & 6.811 & 6.332 & 6.685 \\
\hline Average grade, high school & 84.304 & 9.173 & 84.265 & 8.304 & 84.354 & 8.279 & 84.511 & 8.833 \\
\hline Average wage (DKK) & 300574 & 199968 & 171721 & 207544 & 178437 & 212787 & 183930 & 197212 \\
\hline Years of registered unemployment & 1.149 & 2.005 & 1.241 & 1.979 & 1.170 & 1.898 & 1.163 & 2.076 \\
\hline Married & 0.487 & 0.500 & 0.411 & 0.493 & 0.429 & 0.496 & 0.412 & 0.493 \\
\hline In education & 0.137 & 0.344 & 0.398 & 0.490 & 0.401 & 0.491 & 0.393 & 0.489 \\
\hline Post secondary, tertiary education & 0.588 & 0.492 & 0.807 & 0.395 & 0.805 & 0.397 & 0.805 & 0.397 \\
\hline Education: arts and humanities & 0.142 & 0.349 & 0.183 & 0.387 & 0.181 & 0.386 & 0.181 & 0.386 \\
\hline Education: social science & 0.273 & 0.445 & 0.274 & 0.447 & 0.288 & 0.454 & 0.288 & 0.454 \\
\hline Education: technical & 0.253 & 0.434 & 0.355 & 0.479 & 0.346 & 0.476 & 0.346 & 0.476 \\
\hline High school: no information & 0.606 & 0.489 & 0.330 & 0.471 & 0.332 & 0.472 & 0.363 & 0.481 \\
\hline High school: general & 0.193 & 0.395 & 0.231 & 0.422 & 0.231 & 0.422 & 0.187 & 0.390 \\
\hline High school: math & 0.125 & 0.331 & 0.226 & 0.419 & 0.223 & 0.417 & 0.245 & 0.430 \\
\hline Hich school: language & 0.041 & 0.198 & 0.157 & 0.365 & 0.157 & 0.364 & 0.151 & 0.359 \\
\hline \multicolumn{9}{|l|}{ Region of residence } \\
\hline Copenhagen & 0.312 & 0.463 & 0.223 & 0.417 & 0.217 & 0.413 & 0.247 & 0.432 \\
\hline Zealand $\mathrm{N}$ & 0.112 & 0.315 & 0.056 & 0.230 & 0.049 & 0.217 & 0.055 & 0.228 \\
\hline Zealand S & 0.076 & 0.264 & 0.079 & 0.270 & 0.082 & 0.275 & 0.077 & 0.267 \\
\hline Funen, Bornholm & 0.079 & 0.269 & 0.157 & 0.365 & 0.162 & 0.369 & 0.135 & 0.342 \\
\hline Jutland S & 0.065 & 0.247 & 0.046 & 0.209 & 0.049 & 0.217 & 0.052 & 0.223 \\
\hline Jutland W & 0.095 & 0.294 & 0.063 & 0.244 & 0.063 & 0.244 & 0.058 & 0.233 \\
\hline Jutland $\mathrm{E}$ & 0.177 & 0.381 & 0.231 & 0.422 & 0.234 & 0.424 & 0.277 & 0.448 \\
\hline Jutland $\mathrm{N}$ & 0.080 & 0.271 & 0.142 & 0.350 & 0.140 & 0.348 & 0.099 & 0.299 \\
\hline Region not specified & 0.005 & 0.071 & 0.003 & 0.050 & 0.003 & 0.052 & & \\
\hline \multicolumn{9}{|c|}{ Occupation (from Statistics Denmark's variable 'pstill') } \\
\hline Self-employed & 0.000 & 0.015 & 0.003 & 0.050 & & & & \\
\hline Manager & 0.031 & 0.173 & 0.025 & 0.157 & 0.025 & 0.156 & 0.025 & 0.156 \\
\hline Employee, high level & 0.324 & 0.468 & 0.259 & 0.439 & 0.277 & 0.448 & 0.277 & 0.448 \\
\hline Employee, medium level & 0.123 & 0.328 & 0.074 & 0.261 & 0.077 & 0.267 & 0.077 & 0.267 \\
\hline Employee, basis level & 0.227 & 0.419 & 0.099 & 0.299 & 0.102 & 0.303 & 0.102 & 0.303 \\
\hline Other employee & 0.055 & 0.228 & 0.030 & 0.172 & 0.022 & 0.147 & 0.022 & 0.147 \\
\hline Employee without further information & 0.103 & 0.305 & 0.063 & 0.244 & 0.069 & 0.253 & 0.069 & 0.253 \\
\hline Unemployed & 0.036 & 0.187 & 0.241 & 0.428 & 0.228 & 0.420 & 0.228 & 0.420 \\
\hline Maternity/paternity leave & 0.003 & 0.051 & 0.013 & 0.112 & 0.008 & 0.091 & 0.014 & 0.117 \\
\hline Sickness pay & 0.001 & 0.036 & 0.005 & 0.071 & 0.005 & 0.074 & 0.003 & 0.052 \\
\hline Non-salaried worker & 0.003 & 0.056 & 0.018 & 0.132 & 0.019 & 0.138 & 0.005 & 0.074 \\
\hline Education measure & 0.007 & 0.082 & 0.030 & 0.172 & 0.027 & 0.164 & 0.038 & 0.193 \\
\hline Job market training & 0.003 & 0.055 & 0.005 & 0.071 & 0.003 & 0.052 & 0.003 & 0.052 \\
\hline Social welfare ("revalidering") & 0.001 & 0.035 & 0.003 & 0.050 & 0.003 & 0.052 & 0.005 & 0.074 \\
\hline Unknown & 0.000 & 0.020 & 0.008 & 0.087 & 0.008 & 0.091 & 0.003 & 0.052 \\
\hline Other outside labour force & 0.015 & 0.122 & 0.033 & 0.179 & 0.036 & 0.186 & 0.038 & 0.193 \\
\hline Education & 0.031 & 0.173 & 0.058 & 0.235 & 0.060 & 0.239 & 0.060 & 0.239 \\
\hline \multicolumn{9}{|l|}{ Year } \\
\hline 2005 & 0.436 & 0.496 & 0.234 & 0.424 & 0.225 & 0.418 & 0.225 & 0.418 \\
\hline 2006 & 0.080 & 0.272 & 0.142 & 0.350 & 0.137 & 0.345 & 0.137 & 0.345 \\
\hline 2007 & 0.082 & 0.274 & 0.152 & 0.360 & 0.148 & 0.356 & 0.148 & 0.356 \\
\hline 2008 & 0.077 & 0.266 & 0.140 & 0.347 & 0.143 & 0.350 & 0.143 & 0.350 \\
\hline 2009 & 0.122 & 0.327 & 0.152 & 0.360 & 0.162 & 0.369 & 0.162 & 0.369 \\
\hline
\end{tabular}

Notes: the table shows means and standard deviations for the variables we match persons on. The left column displays descriptive statistics across all persons. The second column refers to persons in the treatment group before data cleaning and matching, column three to treatment group persons after data cleaning and matching and column four corresponds to control group persons after matching. All variables are statistically significant between the treatment and control group before matching but are no longer statistically significant different after matching. 


\begin{tabular}{|c|c|c|c|c|}
\hline & \multicolumn{2}{|l|}{ Adjusted sample } & \multicolumn{2}{|c|}{$\begin{array}{l}\text { Sample of treatments } \\
\text { and controls }\end{array}$} \\
\hline & \multicolumn{2}{|c|}{$N=1,018,245$, LR chi2(78) } & \multicolumn{2}{|c|}{$N=728, L R \operatorname{chi2}(76)=$} \\
\hline & \multirow{2}{*}{\multicolumn{2}{|c|}{$\begin{array}{l}=1129.19, \text { Pseudo } R 2= \\
0.1618\end{array}$}} & \multirow{2}{*}{\multicolumn{2}{|c|}{$25,57, R 2=0.026$}} \\
\hline & & & & \\
\hline & Coeff. & Ste. & Coeff. & Ste. \\
\hline \multicolumn{5}{|l|}{ General information } \\
\hline Female & -0.122 & 0.114 & -0.065 & 0.192 \\
\hline Married & -0.004 & 0.111 & 0.078 & 0.173 \\
\hline In education & -0.050 & 0.181 & 0.009 & 0.310 \\
\hline \multicolumn{5}{|l|}{ Age (in years, omitted: <25years) } \\
\hline$(25,29)$ & $0.750 * * *$ & 0.216 & 0.187 & 0.351 \\
\hline$(30,34)$ & $0.717 * * *$ & 0.256 & 0.304 & 0.427 \\
\hline$(35,39)$ & $0.611 * *$ & 0.301 & 0.316 & 0.503 \\
\hline$(40,44)$ & 0.441 & 0.339 & 0.456 & 0.609 \\
\hline$(45,49)$ & $0.758 * *$ & 0.352 & 0.548 & 0.617 \\
\hline$(50+)$ & 0.024 & 0.359 & 0.688 & 0.610 \\
\hline \multicolumn{5}{|l|}{ Region of residence (omitted: Copenhagen) } \\
\hline Zealand N & 0.325 & 0.243 & 0.142 & 0.406 \\
\hline Zealand S & $1.446 * * *$ & 0.216 & 0.242 & 0.344 \\
\hline Funen, Bornholm & $1.436 * * *$ & 0.171 & 0.372 & 0.273 \\
\hline Jutland S & $1.018 * * *$ & 0.265 & 0.176 & 0.402 \\
\hline Jutland W & $0.784 * * *$ & 0.233 & 0.298 & 0.386 \\
\hline Jutland E & $0.775 * * *$ & 0.151 & -0.063 & 0.237 \\
\hline Jutland $\mathrm{N}$ & $1.269 * * *$ & 0.176 & 0.516 & 0.302 \\
\hline Region not specified & -0.079 & 1.007 & & \\
\hline \multicolumn{5}{|c|}{ High school final grade average (omitted group: unknown) } \\
\hline$(0,75)$ & 0.064 & 0.205 & 0.281 & 0.324 \\
\hline$(76,85)$ & 0.242 & 0.163 & 0.308 & 0.257 \\
\hline$(86,90)$ & -0.227 & 0.210 & 0.502 & 0.350 \\
\hline$(90+)$ & 0.011 & 0.190 & 0.332 & 0.301 \\
\hline \multicolumn{5}{|c|}{ Occupation(from Statistics Denmark's 'pstill' variable, omitted: pstill-category 12 ('VAT-payer')) } \\
\hline Self-employed (pstill=14) & $1.976 *$ & 1.051 & & \\
\hline Manager & 0.774 & 0.475 & -0.047 & 0.794 \\
\hline Employee, high level & 0.270 & 0.348 & -0.090 & 0.557 \\
\hline Employee, medium level & 0.159 & 0.384 & -0.063 & 0.602 \\
\hline Employee, basis level & 0.192 & 0.366 & -0.040 & 0.597 \\
\hline Other employee & 0.702 & 0.438 & -0.058 & 0.771 \\
\hline Employee without further information & 0.372 & 0.379 & -0.016 & 0.621 \\
\hline Unemployed & $1.998 * * *$ & 0.321 & -0.160 & 0.541 \\
\hline Maternity/paternity leave & $1.219 * *$ & 0.543 & -0.604 & 0.923 \\
\hline Sickness pay & $1.681 * *$ & 0.773 & 0.474 & 1.367 \\
\hline Non-salaried worker & $2.551 * * *$ & 0.487 & 0.804 & 0.981 \\
\hline Education measure & $1.909 * * *$ & 0.418 & -0.540 & 0.678 \\
\hline Job market training & $2.808 * * *$ & 0.785 & -0.265 & 1.582 \\
\hline Social welfare ("revalidering") & 1.292 & 1.063 & -0.949 & 1.410 \\
\hline Unknown (pstill=57) & $2.645 * * *$ & 0.663 & 0.842 & 1.298 \\
\hline Other outside labour force & $0.876^{* *}$ & 0.398 & -0.311 & 0.633 \\
\hline Education & 0.415 & 0.378 & -0.095 & 0.606 \\
\hline \multicolumn{5}{|l|}{ Salary (omitted: no information) } \\
\hline$(0 \%, 0.15 \%)$ of sample mean & 0.249 & 0.183 & 0.087 & 0.298 \\
\hline$(15 \%, 25 \%)$ of sample mean & $0.472 * *$ & 0.219 & 0.265 & 0.352 \\
\hline$(25 \%, 50 \%)$ of sample mean & 0.275 & 0.201 & -0.260 & 0.317 \\
\hline$(50 \%, 75 \%)$ of sample mean & $-0.828 * * *$ & 0.287 & -0.033 & 0.450 \\
\hline$(75 \%, 100 \%)$ of sample mean & $-0.784 * * *$ & 0.275 & 0.105 & 0.446 \\
\hline$(100 \%, 125 \%)$ of sample mean & $-1.193 * * *$ & 0.287 & -0.244 & 0.430 \\
\hline$(125 \%, 150 \%)$ of sample mean & $-1.379 * * *$ & 0.302 & -0.115 & 0.444 \\
\hline$(150 \%, 200 \%)$ of sample mean & $-1.527^{* * *}$ & 0.313 & 0.027 & 0.480 \\
\hline$(200 \%+)$ of sample mean & $-1.741 * * *$ & 0.408 & -0.398 & 0.604 \\
\hline
\end{tabular}


Appendix D: firm-level summary statistics

\begin{tabular}{|c|c|c|c|c|c|c|c|c|}
\hline & \multicolumn{2}{|c|}{$\begin{array}{l}\text { Summary of all firms, } \\
N=296,087\end{array}$} & \multicolumn{2}{|c|}{$\begin{array}{l}\text { Summary of adjusted } \\
\text { sample, } N=238.375\end{array}$} & \multicolumn{2}{|c|}{$\begin{array}{l}\text { Summary of treatments } \\
\text { in analysis sample, } N= \\
316\end{array}$} & \multicolumn{2}{|c|}{$\begin{array}{l}\text { Summary of controls in } \\
\text { analysis sample, } \\
N=316\end{array}$} \\
\hline & Mean & Std. Dev & Mean & Std. Dev & Mean & Std. Dev & Mean & Std. Dev \\
\hline \multicolumn{9}{|l|}{ Industry } \\
\hline Construction & 0.13 & 0.34 & 0.15 & 0.36 & 0.06 & 0.23 & 0.05 & 0.22 \\
\hline Trade & 0.18 & 0.39 & 0.19 & 0.39 & 0.21 & 0.41 & 0.21 & 0.41 \\
\hline IT, services & 0.07 & 0.26 & 0.07 & 0.25 & 0.09 & 0.29 & 0.09 & 0.28 \\
\hline Manufacturing & 0.01 & 0.10 & 0.01 & 0.11 & 0.06 & 0.24 & 0.06 & 0.24 \\
\hline Metal industries & 0.02 & 0.14 & 0.02 & 0.15 & 0.05 & 0.22 & 0.03 & 0.18 \\
\hline Furniture and related industries & 0.02 & 0.12 & 0.02 & 0.13 & 0.06 & 0.23 & 0.08 & 0.27 \\
\hline Travel agencies, cleaning services & 0.02 & 0.13 & 0.02 & 0.13 & 0.03 & 0.18 & 0.04 & 0.20 \\
\hline Advertisement & 0.03 & 0.16 & 0.03 & 0.16 & 0.06 & 0.24 & 0.07 & 0.25 \\
\hline Consulting, business services & 0.13 & 0.34 & 0.13 & 0.34 & 0.12 & 0.32 & 0.12 & 0.33 \\
\hline Paper\&publishing & 0.01 & 0.11 & 0.01 & 0.11 & 0.03 & 0.18 & 0.02 & 0.15 \\
\hline Other & 0.38 & 0.48 & 0.35 & 0.48 & 0.22 & 0.42 & 0.23 & 0.42 \\
\hline \multicolumn{9}{|l|}{ Key figures } \\
\hline Number of employees & 11.21 & 64.13 & 7.02 & 12.80 & 14.75 & 18.39 & 13.96 & 17.46 \\
\hline No number of employees information & 0.28 & 0.45 & 0.23 & 0.42 & 0.03 & 0.18 & 0.02 & 0.15 \\
\hline Number of employees $=0$ & 0.13 & 0.34 & 0.11 & 0.31 & 0.01 & 0.11 & 0.02 & 0.14 \\
\hline Number of highly educated employees ${ }^{1}$ & 0.19 & 0.31 & 0.17 & 0.30 & 0.22 & 0.27 & 0.22 & 0.29 \\
\hline Value added (DKK1,000) & 4713 & 39920 & 2903 & 5941 & 6483 & 8425 & 6279 & 8304 \\
\hline No value added information & 0.12 & 0.32 & 0.08 & 0.27 & 0.01 & 0.11 & 0.03 & 0.16 \\
\hline Net income (profit, DKK1,000) & 676 & 25560 & 302 & 1654 & 457 & 2165 & 567 & 2070 \\
\hline Return on assets & -0.41 & 42.66 & 0.02 & 0.23 & 0.03 & 0.21 & 0.04 & 0.22 \\
\hline Wage cost per employee (DKK1,000) & 410 & 1540 & 400 & 660 & 395 & 217 & 377 & 163 \\
\hline No wage cost per employee info. & 0.43 & 0.49 & 0.37 & 0.48 & 0.09 & 0.29 & 0.09 & 0.28 \\
\hline Labour productivity (DKK1,000) & 3096 & 97103 & 2623 & 65175 & 2056 & 5479 & 1867 & 2627 \\
\hline No labour prod. Info. & 0.44 & 0.50 & 0.37 & 0.48 & 0.08 & 0.27 & 0.09 & 0.29 \\
\hline Total assets (DKK1 mio.) & 17.07 & 219.76 & 7.79 & 16.29 & 13.06 & 20.31 & 13.05 & 21.51 \\
\hline Equity share & -1.23 & 99.71 & 0.28 & 0.38 & 0.22 & 0.35 & 0.23 & 0.34 \\
\hline Short term debt $($ DKK1,000) & 7008 & 86627 & 3428 & 6928 & 6532 & 9240 & 6579 & 9931 \\
\hline \multicolumn{9}{|c|}{ Development in selected key figures (average annual increase in $t=-3$ to $t=0$ ) } \\
\hline Number of employees & 0.34 & 9.25 & 0.24 & 2.09 & -0.59 & 4.48 & -0.43 & 4.41 \\
\hline Number of highly educated employees & 0.12 & 2.64 & 0.04 & 0.54 & -1.23 & 3.43 & -1.30 & 3.38 \\
\hline Value added (DKK1,000) & 269 & 7602 & 154 & 1233 & 391 & 1760 & 438 & 1751 \\
\hline Net income & 33.9 & 9435.8 & 2.1 & 860.6 & -2.2 & 1334.5 & 79.0 & 940.5 \\
\hline Wage cost per employee & -4.2 & 1567.3 & -4.2 & 1529.4 & 0.2 & 143.9 & -15.7 & 215.4 \\
\hline Labour productivity & 94.0 & 40919.0 & 74.4 & 22814.4 & -92.7 & 2402.2 & -575.2 & 9857.6 \\
\hline \multicolumn{9}{|l|}{ Year } \\
\hline 2005 & 0.11 & 0.31 & 0.11 & 0.32 & 0.24 & 0.43 & 0.24 & 0.43 \\
\hline 2006 & 0.16 & 0.36 & 0.16 & 0.37 & 0.15 & 0.35 & 0.15 & 0.35 \\
\hline 2007 & 0.18 & 0.39 & 0.18 & 0.39 & 0.15 & 0.36 & 0.15 & 0.36 \\
\hline 2008 & 0.21 & 0.41 & 0.20 & 0.40 & 0.15 & 0.36 & 0.15 & 0.36 \\
\hline 2009 & 0.23 & 0.42 & 0.22 & 0.41 & 0.16 & 0.37 & 0.16 & 0.37 \\
\hline
\end{tabular}




\begin{tabular}{|c|c|c|c|c|c|c|c|c|}
\hline & \multicolumn{2}{|c|}{$\begin{array}{l}\text { Summary of all firms, } \\
N=296,087\end{array}$} & \multicolumn{2}{|c|}{$\begin{array}{l}\text { Summary of adjusted } \\
\text { sample, } N=238.375\end{array}$} & \multicolumn{2}{|c|}{$\begin{array}{l}\text { Summary of treatments } \\
\text { in analysis sample, } N= \\
316\end{array}$} & \multicolumn{2}{|c|}{$\begin{array}{l}\text { Summary of controls in } \\
\text { analysis sample, } \\
N=316\end{array}$} \\
\hline & Mean & Std. Dev & Mean & Std. Dev & Mean & Std. Dev & Mean & Std. Dev \\
\hline \multicolumn{9}{|l|}{ Company age and ownership information } \\
\hline Ownership code: joint stock & 0.27 & 0.44 & 0.27 & 0.44 & 0.52 & 0.50 & 0.53 & 0.50 \\
\hline Company age & 10.45 & 21.80 & 10.24 & 13.45 & 15.10 & 19.87 & 13.94 & 16.32 \\
\hline Company has mother company & 0.34 & 0.47 & 0.34 & 0.48 & 0.48 & 0.50 & 0.49 & 0.50 \\
\hline Company is mother company & 0.06 & 0.24 & 0.05 & 0.23 & 0.11 & 0.31 & 0.09 & 0.29 \\
\hline Company is exporter & 0.12 & 0.32 & 0.12 & 0.32 & 0.42 & 0.49 & 0.39 & 0.49 \\
\hline \multicolumn{9}{|l|}{ Region } \\
\hline Zealand N, Copenhagen & 0.24 & 0.43 & 0.23 & 0.42 & 0.14 & 0.35 & 0.19 & 0.39 \\
\hline Zealand S & 0.09 & 0.28 & 0.09 & 0.28 & 0.04 & 0.19 & 0.04 & 0.19 \\
\hline Funen, Bornholm & 0.11 & 0.31 & 0.12 & 0.32 & 0.15 & 0.35 & 0.16 & 0.37 \\
\hline Jutland S & 0.07 & 0.26 & 0.07 & 0.26 & 0.11 & 0.32 & 0.07 & 0.25 \\
\hline Jutland W & 0.09 & 0.29 & 0.10 & 0.30 & 0.11 & 0.32 & 0.11 & 0.32 \\
\hline Jutland E & 0.09 & 0.28 & 0.09 & 0.29 & 0.10 & 0.30 & 0.07 & 0.26 \\
\hline Jutland N & 0.16 & 0.37 & 0.16 & 0.37 & 0.18 & 0.38 & 0.18 & 0.38 \\
\hline Region not specified, overseas departments & 0.08 & 0.27 & 0.08 & 0.27 & 0.11 & 0.31 & 0.10 & 0.31 \\
\hline \multicolumn{9}{|l|}{ Employee chaacteristics } \\
\hline Company: mean employee age (yrs) & 40.1 & 9.6 & 40.0 & 9.5 & 37.5 & 6.6 & 37.6 & 7.1 \\
\hline Company: share female & 0.26 & 0.29 & 0.25 & 0.29 & 0.30 & 0.26 & 0.27 & 0.26 \\
\hline Company: share with secondary education & 0.26 & 0.34 & 0.24 & 0.33 & 0.31 & 0.28 & 0.30 & 0.32 \\
\hline Company: share with post secondary education & 0.19 & 0.31 & 0.17 & 0.30 & 0.22 & 0.27 & 0.22 & 0.29 \\
\hline Company: share tertiary education & 0.08 & 0.21 & 0.07 & 0.20 & & & & \\
\hline Company: share social science & 0.26 & 0.32 & 0.26 & 0.32 & 0.29 & 0.25 & 0.29 & 0.29 \\
\hline Company: share arts\&hum & 0.26 & 0.32 & 0.26 & 0.32 & 0.29 & 0.25 & 0.29 & 0.29 \\
\hline Company: share technical & 0.35 & 0.35 & 0.35 & 0.35 & 0.30 & 0.28 & 0.32 & 0.33 \\
\hline
\end{tabular}

Notes: the table shows means and standard deviations for the variables we match firms on. The left column displays descriptive statistics across all firms. The second column refers to firms in the treatment group before data cleaning and matching, column three to treatment group firms after data cleaning and matching and column four corresponds to control group firms after matching. All variables are statistically significant between the treatment and control group before matching but are no longer statistically significant different after matching. 
Appendix E: logit regression firm-level estimation results for selection into treatment

\begin{tabular}{|c|c|c|c|c|}
\hline & \multicolumn{2}{|c|}{$\begin{array}{l}\text { Adjusted sample } \\
\qquad N=238,693\end{array}$} & \multicolumn{2}{|c|}{$\begin{array}{l}\text { Treatments and } \\
\text { controls sample } \\
\qquad N=632\end{array}$} \\
\hline & Mean & Std. Dev & Mean & Std. Dev \\
\hline \multicolumn{5}{|l|}{ Industry } \\
\hline Construction & $-0.85 * * *$ & 0.28 & 0.46 & 0.46 \\
\hline Trade & $-0.31 *$ & 0.19 & 0.02 & 0.28 \\
\hline IT, services & -0.16 & 0.25 & 0.28 & 0.40 \\
\hline Manufacturing & $0.90 * * *$ & 0.28 & 0.23 & 0.41 \\
\hline Metal industries & 0.16 & 0.30 & 0.66 & 0.47 \\
\hline Furniture and related industries & $0.55 *$ & 0.28 & -0.27 & 0.40 \\
\hline Travel agencies, cleaning services & 0.48 & 0.34 & -0.31 & 0.51 \\
\hline Advertisement & 0.28 & 0.28 & -0.08 & 0.42 \\
\hline Consulting, business services & -0.19 & 0.24 & 0.13 & 0.36 \\
\hline Paper\&publishing & 0.19 & 0.36 & 0.34 & 0.58 \\
\hline \multicolumn{5}{|l|}{ Other (udeladt category) } \\
\hline \multicolumn{5}{|l|}{ Key figures } \\
\hline Number of employees & $0.04 * * *$ & 0.01 & 0.00 & 0.02 \\
\hline Number of employees^2 & $0.00 * * *$ & 0.00 & 0.00 & 0.00 \\
\hline No employees information & -0.79 & 0.74 & 1.37 & 1.22 \\
\hline Number of employees $=0$ & $-1.18 *$ & 0.69 & 0.40 & 1.04 \\
\hline Value added (DKK1 mio.) & -0.01 & 0.02 & 0.02 & 0.03 \\
\hline No value added information & -0.70 & 0.63 & -0.81 & 0.95 \\
\hline Netincome (DKK1,mio) & -0.04 & 0.04 & -0.04 & 0.07 \\
\hline Return on assets & $0.64 * *$ & 0.32 & 0.32 & 0.53 \\
\hline Wage cost per employee (DKK1,000) & 0.00 & 0.00 & 0.00 & 0.00 \\
\hline No wage cost per employee info. & 0.74 & 0.48 & 0.02 & 0.93 \\
\hline Labour productivity (DKK1,000) & 0.00 & 0.00 & 0.00 & 0.00 \\
\hline No labour prod. Info. & -0.41 & 0.50 & -1.16 & 0.78 \\
\hline Total assets (DKK1 mio.) & 0.01 & 0.01 & 0.01 & 0.02 \\
\hline Total assets $(\mathrm{DKK} 1,000)^{\wedge} 2$ & 0.00 & 0.00 & 0.00 & 0.00 \\
\hline Equity share & $-0.57 * * *$ & 0.17 & -0.35 & 0.33 \\
\hline Short term debt $(\mathrm{DKK} 1,000)$ & 0.00 & 0.00 & 0.00 & 0.00 \\
\hline \multicolumn{5}{|c|}{ Development in selected key figures (average annual increase in $t=-3$ to $t=0$ ) } \\
\hline Number of employees & 0.03 & 0.03 & 0.03 & 0.05 \\
\hline Number of employees, missing obs. & 0.15 & 0.61 & 0.14 & 1.04 \\
\hline Number of highly educated employees & 0.09 & 0.08 & 0.12 & 0.12 \\
\hline Number of highly educated employees, missing & 0.04 & 0.85 & 0.47 & 1.26 \\
\hline Value added (DKK1 mio.) & 0.03 & 0.05 & -0.06 & 0.09 \\
\hline Value added, missing obs. & 0.17 & 0.42 & -0.02 & 0.76 \\
\hline Net income (DKK1 mio.) & -0.03 & 0.08 & 0.00 & 0.11 \\
\hline Wage cost per employee (DKK1,000) & 0.00 & 0.00 & 0.00 & 0.00 \\
\hline Wage cost per employee, missing obs. & 0.74 & 0.48 & 0.02 & 0.93 \\
\hline Labour productivity (DKK1 mio.) & 0.00 & 0.01 & 0.01 & 0.02 \\
\hline Labour productivity, missing obs. & $1.49 * * *$ & 0.45 & 0.56 & 0.71 \\
\hline \multicolumn{5}{|l|}{ Year } \\
\hline 2005 & $0.53^{* * *}$ & 0.19 & -0.06 & 0.29 \\
\hline 2006 & -0.27 & 0.21 & -0.19 & 0.33 \\
\hline 2007 & -0.33 & 0.21 & -0.10 & 0.32 \\
\hline 2008 & $-0.34 *$ & 0.21 & -0.22 & 0.34 \\
\hline 2009 & -0.23 & 0.20 & -0.25 & 0.32 \\
\hline
\end{tabular}




\begin{tabular}{|c|c|c|c|c|}
\hline & \multicolumn{2}{|c|}{$\begin{array}{c}\text { Adjusted sample } \\
\qquad N=238,693\end{array}$} & \multicolumn{2}{|c|}{$\begin{array}{l}\text { Treatments and } \\
\text { controls sample } \\
\qquad N=632\end{array}$} \\
\hline & Mean & Std. Dev & Mean & Std. Dev \\
\hline \multicolumn{5}{|l|}{ Company age and ownership information } \\
\hline Ownership code: joint stock & $0.30^{* *}$ & 0.14 & -0.13 & 0.21 \\
\hline Company age & 0.00 & 0.01 & -0.01 & 0.01 \\
\hline Company age^^2 & 0.00 & 0.00 & 0.00 & 0.00 \\
\hline Company has mother company & 0.06 & 0.12 & -0.07 & 0.19 \\
\hline Company is mother company & 0.18 & 0.19 & 0.23 & 0.31 \\
\hline Company is exporter & $0.99 * * *$ & 0.14 & 0.12 & 0.20 \\
\hline \multicolumn{5}{|l|}{ Region } \\
\hline Zealand N & -0.24 & 0.27 & -0.42 & 0.40 \\
\hline Zealand S & -0.44 & 0.38 & -0.05 & 0.56 \\
\hline Funen, Bornholm & $0.79 * * *$ & 0.28 & -0.06 & 0.43 \\
\hline Jutland S & $0.72 * *$ & 0.29 & 0.64 & 0.46 \\
\hline Jutland W & 0.41 & 0.29 & 0.14 & 0.44 \\
\hline Jutland $\mathrm{E}$ & 0.23 & 0.30 & 0.44 & 0.46 \\
\hline Jutland N & 0.34 & 0.27 & 0.06 & 0.40 \\
\hline Region not specified, overseas departments & $0.67^{* *}$ & 0.29 & 0.26 & 0.45 \\
\hline \multicolumn{5}{|l|}{ Employee chaacteristics } \\
\hline Company: mean employee age (yrs) & $-0.04 * * *$ & 0.01 & 0.00 & 0.01 \\
\hline \multirow[t]{2}{*}{ Company: share female } & 0.00 & 0.24 & 0.25 & 0.42 \\
\hline & 0.78 & 0.47 & 0.41 & 0.82 \\
\hline Company: share with secondary education & 0.16 & 0.38 & 0.03 & 0.64 \\
\hline Company: share with post secondary education & -0.53 & 0.41 & -0.21 & 0.69 \\
\hline Company: share tertiary education & -0.67 & 0.41 & 0.49 & 0.70 \\
\hline Company: share social science & -0.08 & 0.31 & 0.04 & 0.55 \\
\hline \multicolumn{5}{|l|}{ Company: share arts\&hum (ommitted category) } \\
\hline Company: share technical & $-0.73 * *$ & 0.35 & -0.45 & 0.60 \\
\hline
\end{tabular}

